\title{
Sales and Operations Planning: $A$ Business Practice to Align Supply Chains
}

\author{
José Mario Valadez Cedillo, Juan Carlos Pérez García
}

Popular Autonomous University of the State of Puebla, Puebla, Mexico.

\begin{abstract}
Purpose:To summarize the existing knowledge in the scientific literature about the relationship between Sales and Operation Planning (S\&OP) and alignment of the stakeholder in the supply chains.

Design/methodology/approach:Bibliometric research using text mining over 37 selected papers,Scimago Journal Rank Q4 or better.
\end{abstract}

Findings:Our findings suggest that the relationship between $S \& O P$ and alignment has rarely been studied in the academic literature.

Research limitations:These results indicate the need for more studiesto build a theory for alignment based in Sales in Operations Planning practice.

Practical implications: This paper presents a research agenda to close the gap between practice and promise in supply chain management.

Paper type:Literature review.

Originality/value: This paper makes two specific contributions to the literature. First, It provides an agenda for research in functional alignment in the SupplyChain; and next:promotes the need to capitalize on the advantages offered by text mining in the operations planning field.

Keywords- Sales and Operations Planning; S\&OP; alignment; tactical planning; supply chain.

\section{INTRODUCTION}

To successfully face the current competitive environment, companies need to adjust and detail frequently their operational plans, and S\&OPcan perform coordination of the supply chain for a competitive performance (Wang, Hsieh, \& Hsu, 2012).

$\mathrm{S} \& \mathrm{OP}$ is a process that integrates tactical plans of different organizational functions such as sales, marketing, product development, supplies, manufacturing and the financial plan
(Hulthen et al., 2016; Thomé, Scavarda, Fernandez, \& Scavarda, 2012).S\&OP is also defined as the process of developing "tactical plans that assist management in strategically directing the business to achieve continuous competitive advantage" (APICS, 2011)-53).Researchers suggest that $\mathrm{S} \& O P$ is a good practice to make decisions that respond to frequent changes in demand, cost, or other characteristics of market delivery(Coker \&Helo, 2016).

S\&OP process does not have a consensus definition among researchers andpractitioners. However scientific literature agrees that its main purpose is to align functional plans even those part of the supply chain- seeking positive impacts in the use of resources, operating costs and response to the market (de Almeida, Marins, Salgado, Santos, \& da Silva, 2015; Hollmann, Scavarda, \& Thomé, 2015; Kjellsdotter Ivert\& Jonsson, 2010; Kristensen \& Jonsson, 2018; Moon \&Allw, 2015; Sombultawee \& Boonitt, 2018; Steinrücke \& Jahr, 2012).

Recent literature considers the vertical and horizontal alignment of functional plans a key element of S\&OP in different industrial sectors and companies. This is even extended to the external functions of the supply chain(Wagner, Ullrich, \& Transchel, 2014).

The purpose of this article is to summarize the existing knowledge in the scientific literature about the relation between S\&OP and alignment of the stakeholder in the supply chains.This research is a bibliometric study on selected academic papers. It finds that the S\&OP seeks horizontal and vertical alignment in the supply chain, but it doesn't describe detailed specifications of the way in which the alignment takes place, because,despite the wide literature on S\&OP, little has been published on how to enable functional alignment through S\&OP practice. 


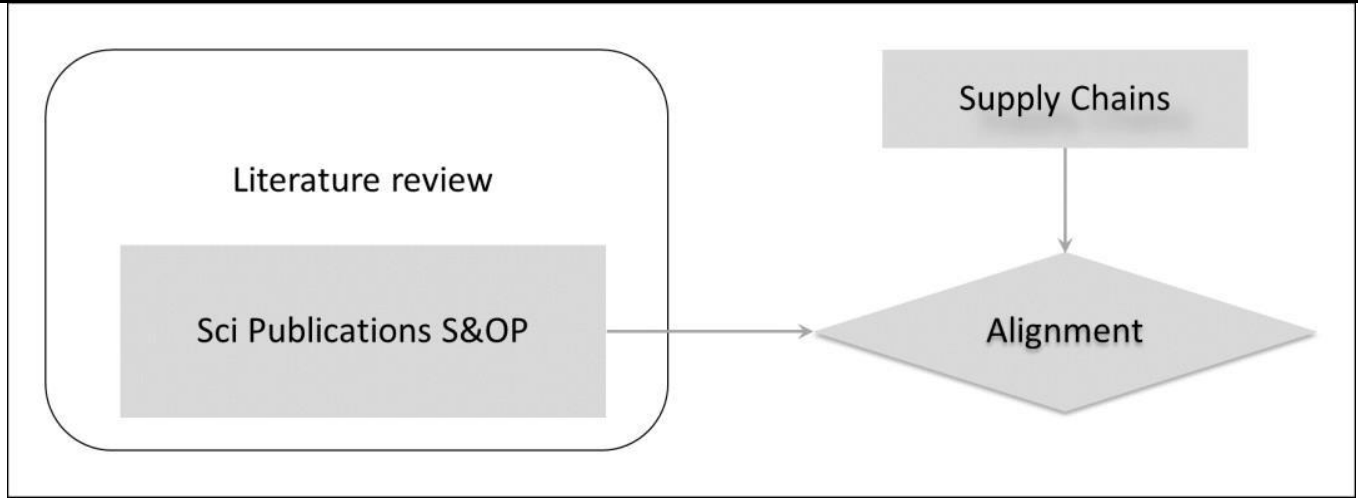

Fig.1: Conceptualization of the construct

Source:Own elaboration, 2018.

Literature makes clear that alignment is mandatory and a quality difficult to achieve in the practice, even if it might seem simple at first sight (Wagner et al., 2014). A better understanding of how alignment occurs would allow managers to react quickly to changes in the competitive environment.

\section{LITERATURE REVIEW}

The S\&OP is part of the disciplines of operations planning(Olhager, 2013), and its first references in the scientific literature date from the end of the last century (Thomé et al., 2012). The selected literature does not refer to a single S\&OP model, but to its different interpretations according to the context in which it is applied (Thomé et al., 2012). The characteristic that is shared between the different interpretations, is that it produces alignment among the business stakeholders (Wagner et al., 2014).

\section{1- Operations Planning}

The focal point in operations planning has evolved from a basic level to a more complex one; from Shop Floor Control in the 1960s, to Supply Chain Planning in 2000s, S\&OP practice was the focal point during the 1990s (Figure 2). In their search for greater competitiveness, organizations have increasingly incorporated a greater number of criteria to make the most of their operating resources (Olhager, 2013).

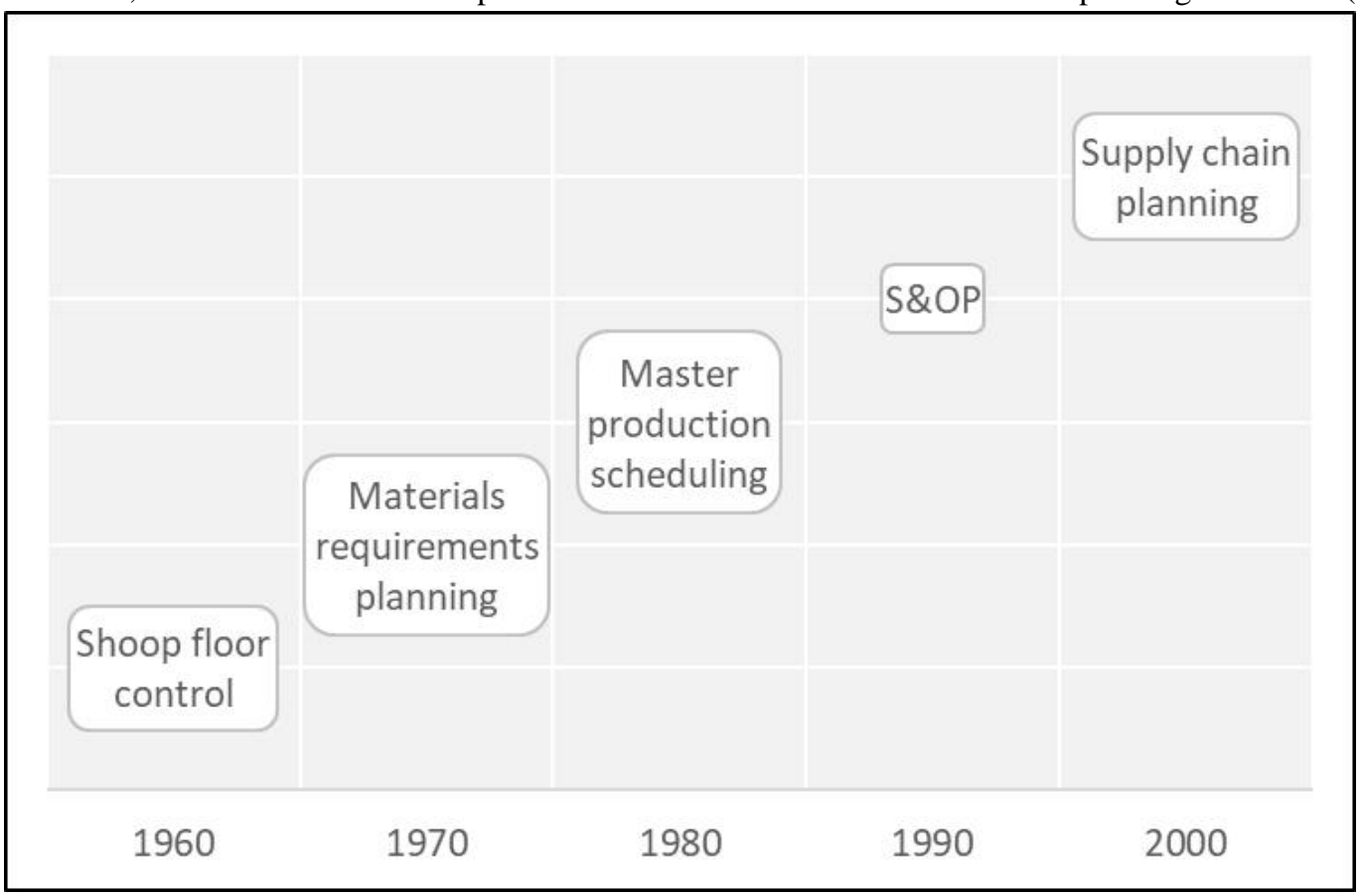

Fig.2: Evolution of the focal point in planning operations

Source: Olhager, 2013. 


\subsection{Sales and Operations Planning}

The Council of Supply Chain Management Professionals -a leading professional association for supply chain and operations-,defines S\&OP as a process that "reconciles conflicted business objectives"(Vitasek, 2013). In the same way, Tuomikangas and Kaipia (2014) point out that S\&OP is a valuable process for achieving business' strategic objectives. The alignment of tactical plans in different departments of the organization allows establishing a link between the short-term goals and the strategic objectives of the company to maximize results(Wagner et al., 2014).

The practice of S\&OP has its background during the 1950s decade, specifically at Holt, Modigliani, Muth and Simon's work on operations management (Noroozi \& Wikner, 2012). S\&OP literature started in 1998 (Thomé et al., 2012)at an upward in from 1998 to 2010 (Figure 3).

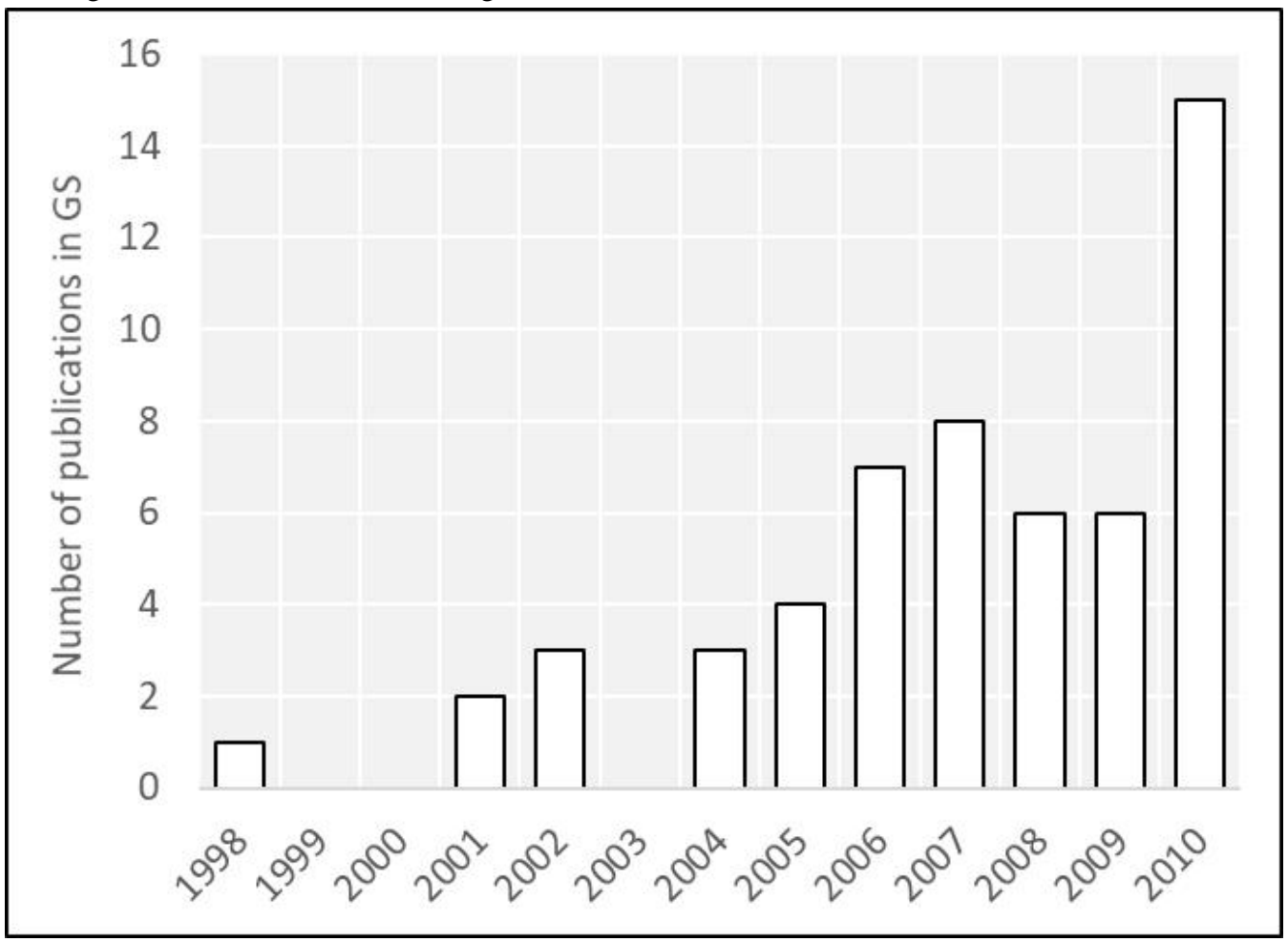

Fig.3: Number of publications on S\&OP per year in Google Scholar

Source: Thomé et al, 2012.

\subsection{Contextual design}

Has been established that S\&OP can have different objectives in different companies; and that the process and its activities are also changeable, especially when they respond to the conditions of the industrial sector and the company's strategy(Thomé et al., 2012). The investigation of operational planning and S\&OP has been carried out on different industrial sectors (Table 1).

\section{Table 1: Papers by Sector}

\begin{tabular}{|l|l|}
\hline Automotive & $\begin{array}{l}\text { (Lim, Alpan, \& Penz, 2014; Plank \& } \\
\text { Hooker, 2014; Scarvada et al., 2014) }\end{array}$ \\
\hline Food & $\begin{array}{l}\text { (Christopher \& Ryals, 2014; Ivert, } \\
\text { Dukovska-Popovska, Fredriks son, } \\
\text { Dreyer, \& Kaipia, 2015; Ivert et al., } \\
\text { 2014) }\end{array}$ \\
\hline
\end{tabular}

\begin{tabular}{|l|l|}
\hline Dairy & $\begin{array}{l}\text { (Nemati, Madhoshi, \& Ghadikolaei, } \\
2017)\end{array}$ \\
\hline Cosmetics & $\begin{array}{l}\text { (Hulthen et al., 2016; Rojas \& Hazin, } \\
2014)\end{array}$ \\
\hline $\begin{array}{l}\text { Discrete } \\
\text { Manufacturing }\end{array}$ & $\begin{array}{l}\text { (Noroozi, 2017; Noroozi \& Wikner, } \\
\text { 2016) }\end{array}$ \\
\hline Process Industry & $\begin{array}{l}\text { (Noroozi \& Kumar, R. and } \\
\text { Srivastava, 2014; Noroozi \& Wikner, } \\
2012, \text { 2017) }\end{array}$ \\
\hline Paper & (Naslund \& Williamson, 2017) \\
\hline Reverse Clothing & $\begin{array}{l}\text { (Sandberg, Pal, \& Hemilä, 2018) } \\
\text { Supply Chain }\end{array}$ \\
\hline Grocery Retailing & $\begin{array}{l}\text { (Dreyer, Kiil, Dukovska-Popovska, } \\
\text { \& Kaipia, 2018) }\end{array}$ \\
\hline
\end{tabular}

Source: Own elaboration, 2018. 
Due to the nature of its context-based design(Kristensen \& Jonsson, 2018), in literature,S\&OP practice is named in various ways through literature (table 2).

Table 2: Names used to refer practice of $S \& O P$

\begin{tabular}{|c|l|}
\hline SIOP & Sales operations and inventory planning \\
\hline IBP & $\begin{array}{l}\text { Integrated busines planning; profit, sales, and } \\
\text { operations planning; }\end{array}$ \\
\hline & Supply chain sales and operations planning \\
\hline & $\begin{array}{l}\text { Sales/production sales and operations } \\
\text { planning }\end{array}$ \\
\hline & Global sales and operations planning \\
\hline DSI & Executive sales and operations planning \\
\hline
\end{tabular}

Source: Own elaboration with information

of Kristensen and Jonss on, 2018.

\subsection{Alignment}

Alignment, together with agility and adaptability, allows organizations to deal favorably with changes in the competitive environment (Dubey, Altay, Gunasekaran, Papadopoulos, \& Childe, 2017), linking the long-term strategic goals with the planning of short-term operations (Danese, Molinaro, \& Romano, 2017). Alignment is favored by management's commitment to establish incentives (Panahifar, Heavey, Byrne, \& Fazlollahtabar, 2015), to provide connectivity to the supply chain and exchange information (Dubey et al., 2017).

The alignment of organizations occurs at three levels: strategic, tactical and operational (Sombultawee \& Boon-itt, 2018). Top management must establish an adequate governance structure for executing the customer value creation strategy, by aligning the stakeholders with the clients. There is no generalized theory about alignment that can be applied (Sombultawee \& Boon-itt, 2018), it is a nonunidirectional process, involving work and learning (Selviaridis, Spring, \& Authors, 2018). Alignment is a complex result, although literature points out that the alignment between stakeholders is important to improve business performance, there are other types of alignment that must be considered (Skipworth, Godsell, Wong, Saghiri, \& Julien, 2015) and on which it is necessary to deepen the current knowledge.

Collaboration for alignment in practice planning is affected by different variables (Table 3 ) on their own reach and
depth(Hollmann et al., 2015; Kristensen \& Jonsson, 2018;

Nabil, El Barkany, \& El Khalfi, 2018).

Table 3: Factors affecting collaboration in planning

- Demand elasticity.

- Market uncertainty and lead times.

- Goals of the process: responsiveness vs efficiency.

- Supply uncertainty.

- Supply Chain spatial complexity: number of partners and geographical distance.

- Company complexity; firm size.

- Hierarchical planning framework: linking strategic planning with tactical planning or tactical planning with the operational plan.

- The maturity of planning framework.

- Organizational characteristics: human, technological and characteristics of the organization: external and internal integration.

- A number of products: same or different products.

Source: Own elaboration, with

information ofHollmann et al., (2015);

Kristensen \& Jonsson, (2018); Nabil et al.,

(2018); Wagneret al., (2014).

\section{RESEARCH METHODOLOGY}

The methodology applied is a bibliometric study in 4 steps (Figure 4).In the first step, 37 documents of ProQuest and EBSCOhost Research Databases were selected with the search terms "Sales and Operations Planning"; "Sales \&Operations Planning"; "S\&OP" and "Supply Chain Alignment". The search was also limited to articles published from the year 2014 onwards and to journals ranked inScimago Journal Rank on Q4 or better.

For steps 2 to 3 the text mining system "Enterprise Miner 14.1"Advanced Analytics Software | SAS https://www.sas.com/)was used processing summary, author, year of publication, journal,and ranking of the journal of selected research.

The second step wasText Parsing and Filter, to quantify selected information about the terms that are contained in abstracts. The third step was Clustering data, classifying and establishing relationships between the concepts contained in the selected documents.

The fourth step was the analysis of the processed information. 


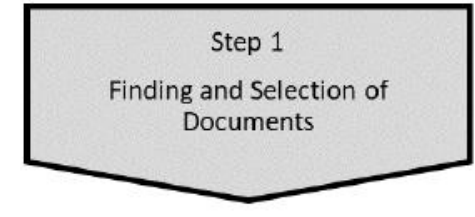

Step 2

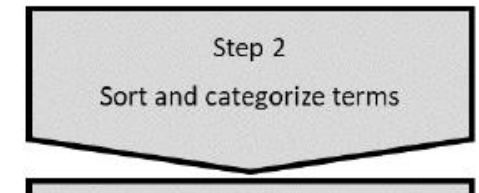

Step 3

Group terms and quantify incidents

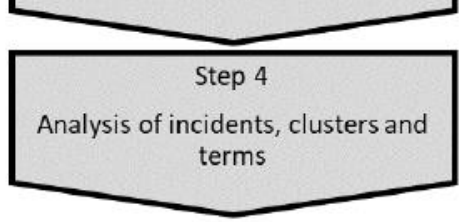

37 DOCUMENTS

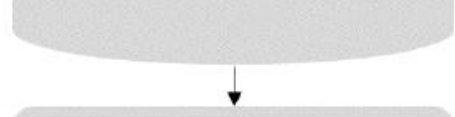

Parsing and Filtering texts

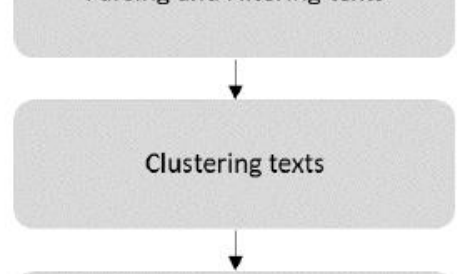

Cuantiificar incidencias

Fig.4: Research Methodology

Resource: Own elaboration, 2018.

\section{RESULTS}

The number of papers from 2013 to 2017 is between 6 and 9, the data from 2018 is partial to March(figure 4).

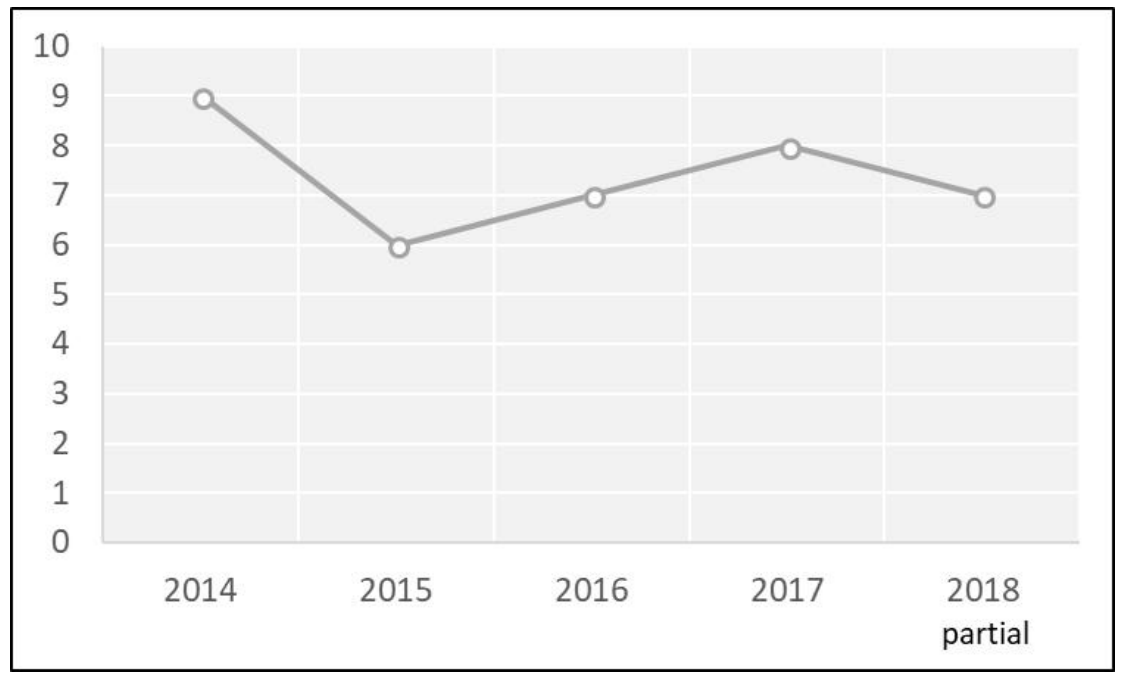

Fig.4: Number of research publications for the year

Source: Own elaboration, 2018.

The documents were selected from 22 journals, 1 of them contributed with 5 papers (International Journal of Physical Distribution and Logistics Management), 16 of them with only 1 (Appendix 1). 14 journals and 28 papers belong to the rank Q1 (Figure 5).
The authors of the papers are 104 and they are in 20 countries (Appendix 2). Most of the contributions are from Sweden (14\%), and the USA:(13\%) while $66 \%$ of the authorship is covered in 6 countries: USA, United Kingdom, Finland, Brazil and Denmark (Figure 6). 


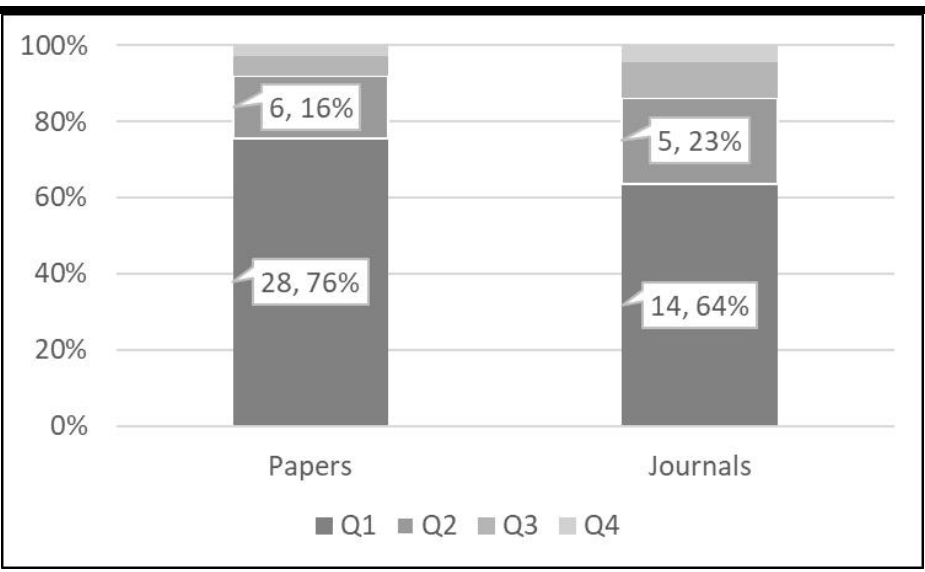

Fig.5: Distribution of papers and journals by SJR Rank

Source: Own elaboration, 2018

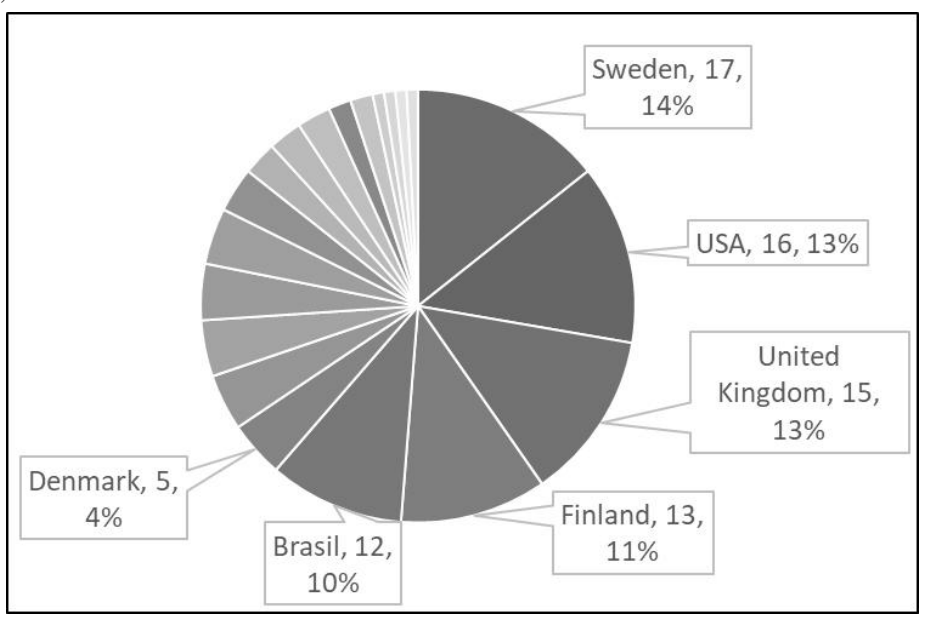

Fig.6: Authorship byCountry

Source: Own elaboration, 2018

The term "Sales and Operations Planning" appears with a frequency of 147 in 20 papers; the term 'alignment' appears with a frequency of 41 in 11 papers and the term 'supply chain' appears 51 times in 19 papers (Figure 7).

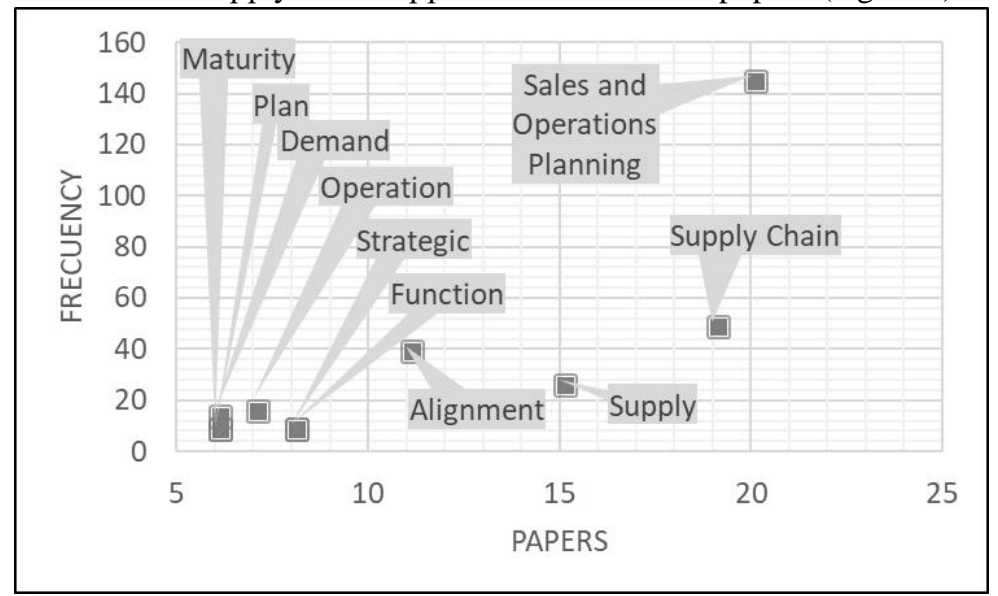

Fig.7: Number of Papers by Frequency of Terms

Source: Own elaboration, 2018

The relationship analysis of concepts, shows that the term 'supply chain' is directly related to the terms 'Sales and Operations Planning' and 'alignment', while these only have an indirect relation to each other (Figure 8).
Cluster analysis, obtained with the ExpectationMaximization clustering algorithm with using a Hierarchical clustering algorithm, with 4 descriptive terms, produced 5 clusters (Table 4 ). 
The relationship of the frequency and quality of the grouping measured with the Root Mean Square Standardized (RMS Std.) is shown in Figure 9, and in
Figure 10 the frequency of the clusters in the analyzed documents is shown.

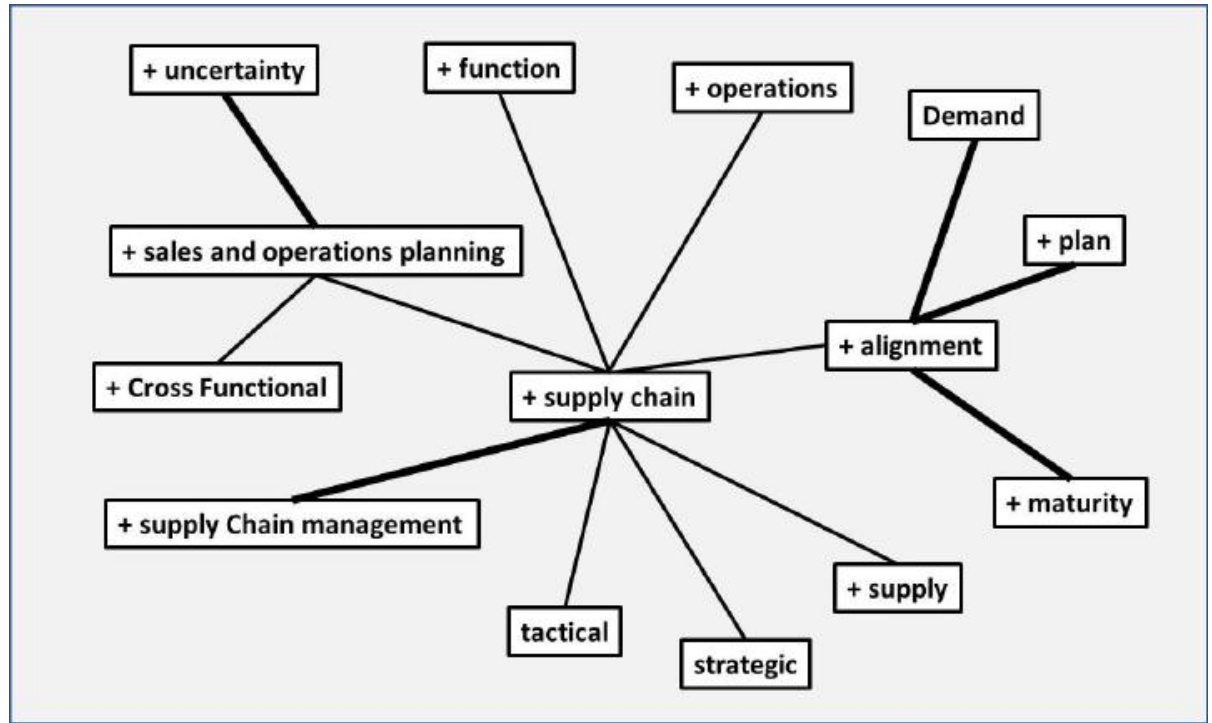

Fig.8: Concept linking between $S \& O P$, Supply Chain and Alignment

Source: Own elaboration, 2018

Table 4: Clusters

\begin{tabular}{|c|l|c|c|}
\hline Cluster & Descriptive terms & Frequency & RMS Std. \\
\hline 1 & [strategic] [tactical] [alignment] [coordination] & 8 & 0.18565 \\
\hline 2 & [maturity] [Sales and Operations Planning] [plan] [market] & 11 & 0.191357 \\
\hline 3 & [operations] [function] [Croos Functional] [demand] & 4 & 0.194552 \\
\hline 4 & $\begin{array}{l}\text { [Tactical planning] [integration mechanism] [Supply Chain Management] } \\
\text { [supply chain] }\end{array}$ & 9 & 0.301199 \\
\hline 5 & [Operations Planning] [contextual] [uncertainty] [Supply Chain Management'] & 5 & 0.22495 \\
\hline
\end{tabular}

Source: Own elaboration, 2018.

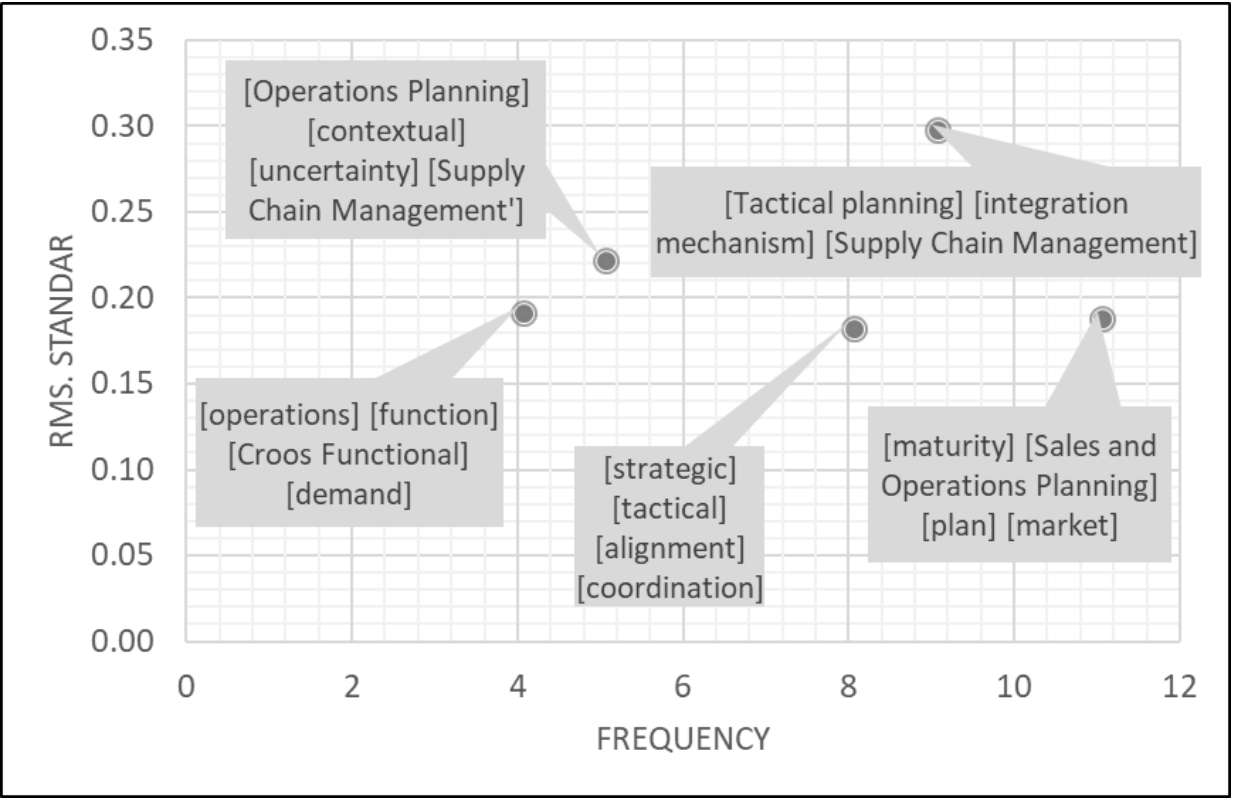

Fig.9: Relationship of the frequency and quality of the clustering

Source: Own elaboration, 2018. 


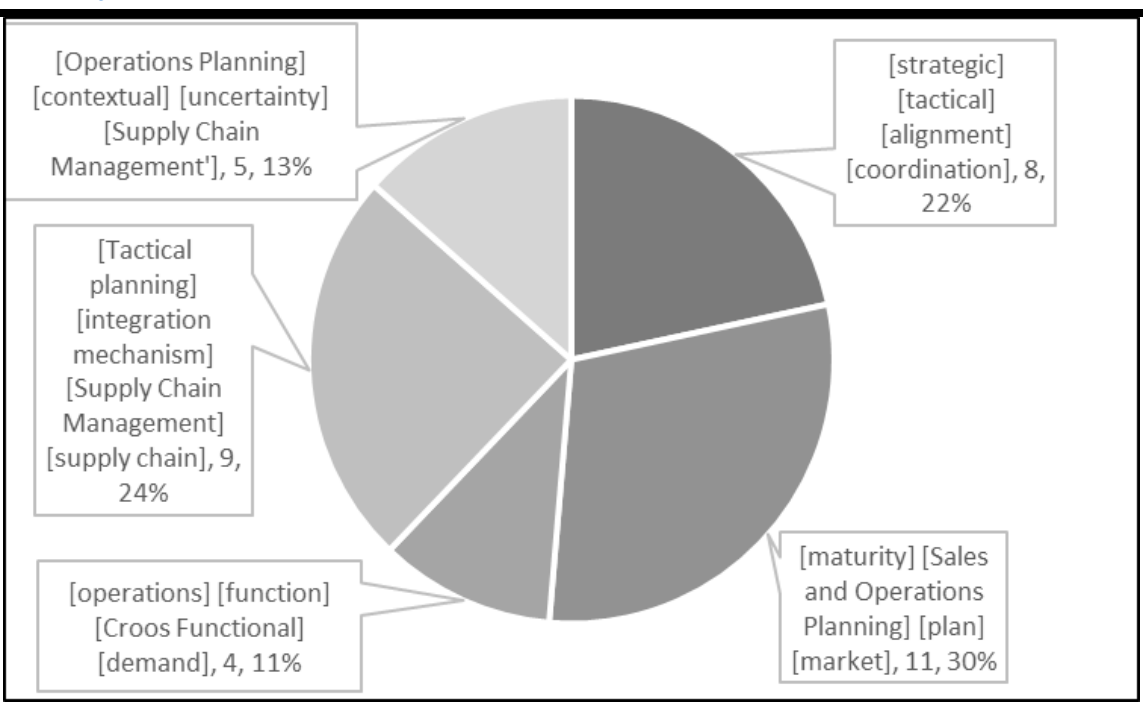

Fig.10: Frequency of clusters

Source: Own elaboration, 2018.

\section{DISCUSSION}

Through the analysis of text mining, it was not possible to find a direct relationshipbetween the terms: "alignment" and "S\&OP" (figure 8)."Alignment" appears in clusters analys is in the relationship with terms: "Strategic", "Tactic" and "Collaboration", which reveals the areas of interest that academics haverelated with the term alignmentin their researches.

S\&OP forms the cluster most frequently with 'maturity', 'plan' and 'market': $30 \%$ (figure 10). Maturity is one of the factors that affect collaboration (Table 3), so we can suspect that the research in S\&OP has an important orientation to the maturity of the planning process and its relationship with the market.

\section{CONCLUSION}

This manuscript establishes a broad field of research because the alignment of the stakeholders is an important factor for the maintenance and development of competitiveness. The construction of a theory about how the alignment is achieved will allow practitioners to improve the performance of their businesses. This manuscript also opens the way to the use of text mining technology in the field; sparingly used to date. In futures researches, it is convenient to consider a greater number of articles, to expand the amount of text considered in each document, not to limit it to the summaries and to extend the range of years considered to identify trends with greater clarity; and above all: to make a deeper use of the text mining tool.

\section{ACKNOWLEDGMENT}

www.jiaems.com
The authors are grateful for the support of the company ITEIN (www.itein.com.mx) for the habilitation and training in the text mining tool used for this analysis.

\section{REFERENCES}

[1] APICS. (2011). APICS: Operations Management Body of Knowledge Framework. Retrieved from http://www.apics .org/sites/apics -s upply-chaincouncil/research-and-publications/ombok

[2] Christopher, M., \& Ryals, L. J. (2014). The Supply Chain Becomes the Demand Chain. Journal of Business $\quad$ Logistics, 35(2), 155-156. https://doi.org/10.1111/jbl.12048

[3] Coker, J., \& Helo, P. (2016). Demand-supply balancing in manufacturing operations. Benchmarking, 23(3), 564-583. https://doi.org/10.1108/BIJ-04-20140028

[4] Danese, P., Molinaro, M., \& Romano, P. (2017). Managing evolutionary paths in Sales and Operations Planning: key dimensions and sequences of implementation. International Journal of Production Research, 7543(July), 1-18. https://doi.org/10.1080/00207543.2017.1355119

[5] de Almeida, M. M. K., Marins, F. A. S., Salgado, A. M. P., Santos, F. C. A., \& da Silva, S. L. (2015). Mitigation of the bullwhip effect considering trust and collaboration in supply chain management: a literature review. International Journal of Advanced Manufacturing Technology, 77(1-4), 495-513. https://doi.org/10.1007/s00170-014-6444-9

[6] Dreyer, H. C., Kiil, K., Dukovska-Popovska, I., \& Kaipia, R. (2018). Proposals for enhancing tactical 
planning in grocery retailing with S\&OP. International

Journal of Physical Distribution \& Logistics Management, 48(2), 114-138. https://doi.org/10.1108/IJPDLM-01-2017-0018

[7] Dubey, R., Altay, N., Gunasekaran, A., Papadopoulos, T., \& Childe, S. J. (2017). Supply Chain Agility, Adaptability And Alignment: Empirical Evidence From The Indian Auto Components Industry. International Journal of Operations \& Production Management.

[8] Hollmann, R. L., Scavarda, L. F., \& Thomé, A. M. T. (2015). Collaborative planning, forecasting and replenishment: a literature review. International Journal of Productivity and Performance Management, 64(7), 971-993. https://doi.org/10.1108/IJPPM-03-2014-0039

[9] Hulthen, H., Näslund, D., Norrman, A., Hulthén, H., Näslund, D., Norrman, A., ... Norrman, A. (2016). Framework for measuring performance of the sales and operations planning process. International Journal of Physical Distribution \& Logistics Management, 46(9), 809-835. https://doi.org/10.1108/IJPDLM-052016-0139

[10] Ivert, L. K., Dukovska-Popovska, I., Fredriksson, A., Dreyer, H. C., \& Kaipia, R. (2015). Contingency between S\&OP design and planning environment. International Journal of Physical Distribution \& Logistics Management, 45(8), 747-773. https://doi.org/10.1108/IJPDLM-04-2014-0088

[11] Ivert, L. K., Dukovska-Popovska, I., Kaipia, R., Fredriksson, A., Dreyer, H. C., Johansson, M. I., ... Tuomikangas, N. (2014). Sales and operations planning: Responding to the needs of industrial food producers. Production Planning and Control, 26(4), 280-295.

https://doi.org/10.1080/09537287.2014.897769

[12] Kjellsdotter Ivert, L., \& Jonsson, P. (2010). The potential benefits of advanced planning and scheduling systems in sales and operations planning. Industrial Management \& Data Systems, 110(5), 659-681. https://doi.org/10.1108/02635571011044713

[13] Kristensen, J., \& Jonsson, P. (2018). Context-based sales and operations planning (S\&OP) research. International Journal of Physical Distribution \& Logistics Management, 48(1), 19-46. https://doi.org/10.1108/IJPDLM-11-2017-0352

[14] Lim, L. L., Alpan, G., \& Penz, B. (2014). A Simulation-Optimization Approach for Managing the Sales and Operations Planning in the Automotive Industry.
[15] Moon, M., \& Allw, P. (2015). From Sales \& Operations Planning to Business Integration. International Journal of Applied Forecasting, Spring, 5-12. Retrieved from http://search.ebscohost.com/login.aspx?direct=true\&d $\mathrm{b}=\mathrm{bth} \& \mathrm{AN}=102026375$ \& site $=$ ehost-live

[16] Nabil, L., El Barkany, A., \& El Khalfi, A. (2018). Sales and Operations Planning (S\&OP) Concepts and Models under Constraints: Literature Review. International Journal of Engineering Research in Africa, 34, 171-188. https ://doi.org/10.4028/www.scientific.net/JERA.34.1 71

[17] Naslund, D., \& Williamson, S. (2017). SALES AND OPERATIONS PLANNING - A POTENTIAL STRATEGIC TOOL FOR THE US PAPER INDUSTRY. Journal of International Business Disciplines, 12(2), 1-16.

[18] Nemati, Y., Madhoshi, M., \& Ghadikolaei, A. S. (2017). The effect of Sales and Operations Planning (S\&OP) on supply chain's total performance: A case study in an Iranian dairy company. Computers and Chemical Engineering, 104, 323-338. https://doi.org/10.1016/j.compchemeng.2017.05.002

[19] Noroozi, S. (2017). Sales and operations planning based on a modularized view of supply chains Supporting process industries and discrete manufacturing industries. International Journal of Production Economics.

[20] Noroozi, S., \& Kumar, R. and Srivastava, S. K. (2014). A Framework for Sales and Operations Planning in Process Industries. Metamorphosis: A Journal of Management Research (Vol. 13). https://doi.org/10.1177/0972622520140104

[21] Noroozi, S., \& Wikner, J. (2012). Sales and operations planning in the process industry. Linköpings Universitet Publikationer, 10. Retrieved from https://www.iei.liu.se/prodek/pic/publikationer/1.5499 42/Sales andoperations planningintheproces sindustry.pd f

[22] Noroozi, S., \& Wikner, J. (2016). A modularized framework for sales and operations planning with focus on process industries. Production and Manufacturing Research, 4(1), 65-89. https://doi.org/10.1080/21693277.2016.1200502

[23] Noroozi, S., \& Wikner, J. (2017). Sales and operations planning in the process industry: A literature review. International Journal of Production Economics. https://doi.org/10.1016/j.ijpe.2017.03.006

[24] Olhager, J. (2013). Evolution of operations planning 
and control: From production to supply chains. International Journal of Production Research, 51(2324), 6836-6843.

https://doi.org/10.1080/00207543.2012.761363

[25] Panahifar, F., Heavey, C., Byrne, P., \& Fazlollahtabar, H. (2015). A framework for Collaborative Planning, Forecasting and Replenishment (CPFR). Journal of Enterprise Information Management (Vol. 28). https://doi.org/10.1108/JEIM-09-2014-0092

[26] Plank, R. E., \& Hooker, R. (2014). Sales and operations planning. Journal of Research in Interactive $\quad$ Marketing, $8(1), \quad$ 18-36. https://doi.org/10.1108/JRIM-08-2013-0059

[27] Rojas, X., \& Hazin, L. (2014). Estructura de Gestión basada en el proceso S\&OP: Estudio de caso en unaindustria cosmética Brasileña. Enfoque UTE, 5(1), $1-15$.

[28] Sandberg, E., Pal, R., \& Hemilä, J. (2018). Exploring value creation and appropriation in the reverse clothing supply chain. International Journal of Logistics Management, 29(1), 90-109. https://doi.org/10.1108/IJLM-10-2016-0241

[29] Scarvada, L. F., Hellingrath, B., Kreute, T., Tavares Thomé, A. M., Seeling, M. X., Fisher, J.-H., \& Mello, R. (2014). The impact of sales and operations planning practices on manufacturing operational performance. International Journal of Production Research, 52(7), 2108-2121.

https://doi.org/10.1080/00207543.2013.853889

[30] Selviaridis, K., Spring, M., \& Authors, F. (2018). Supply chain alignment as process: contracting, learning and pay-for-performance. International Journal of Operations \& Production Management, 38(3), 732-755. https://doi.org/10.1108/IJOPM-01-
2017-0059

[31] Skipworth, H., Godsell, J., Wong, C. Y., Saghiri, S., \& Julien, D. (2015). Supply chain alignment for improved business performance: an empirical study. Supply Chain Management, 20(5), 511-533. https://doi.org/10.1108/SCM-06-2014-0188

[32] Sombultawee, K., \& Boon-itt, S. (2018). Marketingoperations alignment: A review of the literature and theoretical background. Operations Research Perspectives, 5, 1-12. https://doi.org/10.1016/j.orp.2017.11.001

[33] Steinrücke, M., \& Jahr, M. (2012). Tactical planning in supply chain networks with customer oriented single sourcing. International Journal of Logistics Management, 23(2), 259-279. https://doi.org/10.1108/09574091211265387

[34] Thomé, A. M. T., Scavarda, L. F., Fernandez, N. S., \& Scavarda, A. J. (2012). Sales and operations planning: A research synthesis. International Journal of Production Economics, 138(1), 1-13. https://doi.org/10.1016/j.ijpe.2011.11.027

[35] Vitasek, K. (2013). Supply chain management: Terms and Glossary. ((Council of Supply Chain Management Professionals ),

Ed.). https://doi.org/10.1201/9781420025705.ch2

[36] Wagner, S. M., Ullrich, K. K. R., \& Transchel, S. (2014). The game plan for aligning the organization. Business Horizons, 57(2), 189-201. https://doi.org/10.1016/j.bushor.2013.11.002

[37] Wang, J.-Z., Hsieh, S.-T., \& Hsu, P.-Y. (2012). Advanced sales and operations planning framework in a company supply chain. International Journal of Computer Integrated Manufacturing, 25(3), 248-262. https://doi.org/10.1080/0951192X.2011.629683

Appendix 1

Journals, SJR Rank and papers

\begin{tabular}{|clc|}
\hline $\begin{array}{c}\text { SJR } \\
\text { Rank }\end{array}$ & \multicolumn{1}{c|}{ Journal } & No. \\
Q1 & International Journal of Physical Distribution and Logistics Management \\
Q1 & Journal of Business Logistics & 6 \\
Q1 & International Journal of Production Research & 3 \\
Q1 & International Journal of Operations and Production Management & 3 \\
Q1 & International Journal of Production Economics & 3 \\
Q1 & International Journal of Logistics Management & 3 \\
Q1 & Production Planning and Control & 2 \\
Q1 & Computers in Industry & 1 \\
Q1 & Business Horizons & 1 \\
Q1 & Journal of Operations Management & 1 \\
\hline
\end{tabular}




$\begin{array}{ll}\text { Q1 } & \text { Computers and Chemical Engineering } \\ \text { Q1 } & \text { Supply Chain Management } \\ \text { Q1 } & \text { International Journal of Advanced Manufacturing Technology } \\ \text { Q1 } & \text { International Journal of Productivity and Performance Management } \\ \text { Q2 } & \text { Benchmarking } \\ \text { Q2 } & \text { Operations Research Perspectives } \\ \text { Q2 } & \text { Production and Manufacturing Research } \\ \text { Q2 } & \text { Dyna } \\ \text { Q2 } & \text { Journal of Research in Interactive Marketing } \\ \text { Q3 } & \text { International Journal of Supply Chain Management } \\ \text { Q3 } & \text { Academy of Marketing Studies Journal } \\ \text { Q4 } & \text { International Journal of Engineering Research in Africa }\end{array}$

Source: Own elaboration, 2018.

Appendix 2

Authors, country paperssorted by number of papers, country and name)

\begin{tabular}{|c|c|c|c|c|c|}
\hline Author & Country & Total & Author & Country & Total \\
\hline Kaipia, Riikka & $\begin{array}{l}\text { Finland/S } \\
\text { weden }\end{array}$ & 5 & Nabil, Lahloua & Morocco & 1 \\
\hline Dukovska-Popovska, Iskra & Denmark & 3 & El Barkany, Abdellah & Morocco & 1 \\
\hline Dreyer, Heidi Carin & Norway & 3 & El Khalfi, Ahmed & Morocco & 1 \\
\hline Thomé, Antônio Márcio Tavares & Brasil & 2 & Chabada, Lukas & Norway & 1 \\
\hline Holmström, Jan & Finland & 2 & Kiil, Kasper & Norway & 1 \\
\hline Tuomikangas, Nina & Finland & 2 & Sousa, Rui Soucasaux & Portugal & 1 \\
\hline Fredriksson, Anna & Sweden & 2 & Sandberg, Erik & Sweden & 1 \\
\hline Ivert, Linea Kjells dotter & Sweden & 2 & Norrman, Andreas & Sweden & 1 \\
\hline Da Silva, Andrea Lago & Brasil & 1 & Näslund, Dag & Sweden & 1 \\
\hline da Silva, Sérgio Luis & Brasil & 1 & Noroozi, Sayeh & Sweden & 1 \\
\hline de Almeida, Marly MizueKaibara & Brasil & 1 & Pal, Rudrajeet & Sweden & 1 \\
\hline $\begin{array}{l}\text { Do Carmo, Luiz Felipe Roris } \\
\text { Rodriguez Scavarda }\end{array}$ & Brasil & 1 & Hulthen, Hana & Sweden & 1 \\
\hline Salgado, Andréia Maria Pedro & Brasil & 1 & Johansson, Mats I. & Sweden & 1 \\
\hline Scavarda, Luiz Felipe & Brasil & 1 & Kjells dotter Ivert, Linea & Sweden & 1 \\
\hline Pedroso, Carolina Belotti & Brasil & 1 & Kristensen, Jesper & Sweden & 1 \\
\hline Hollmann, Roberto Luis & Brasil & 1 & Wikner, Joakim & Sweden & 1 \\
\hline Santos, Fernando César Almada & Brasil & 1 & Wagner, Stephan M. & Switzerland & 1 \\
\hline Marins, Fernando Augusto Silva & Brasil & 1 & Boon-itt, Sakun & Thailand & 1 \\
\hline Gaudreault, Jonathan & Canada & 1 & Sombultawee, Kedwadee & Thailand & 1 \\
\hline Thomas, André & Canada & 1 & Childe, Stephen J. & United Kingdom & 1 \\
\hline Wery, Jean & Canada & 1 & Christopher, Martin & United Kingdom & 1 \\
\hline Damgaard, Cecilie Maria & Denmark & 1 & Selviaridis, Kostas & United Kingdom & 1 \\
\hline Sablón Cossío, Neyfe & Ecuador & 1 & Wong, Chee Yew & United Kingdom & 1 \\
\hline Coker, Joakim & Finland & 1 & Papadopoulos, Thanos & United Kingdom & 1 \\
\hline Helo, Petri & Finland & 1 & Eldrige, Stephen & United Kingdom & 1 \\
\hline Rajala, Risto & Finland & 1 & Godsell, Janet & United Kingdom & 1 \\
\hline Hemilä, Jukka & Finland & 1 & Goh, Shao Hung & United Kingdom & 1 \\
\hline Småros, Johanna & Finland & 1 & Blome, Constantin & United Kingdom & 1 \\
\hline
\end{tabular}


Appendix 2

Authors, country paperssorted by number of papers, country and name)

\begin{tabular}{|llc|llc|}
\hline Author & Country & Total & Author & Country & Total \\
\hline Dubey, Rameshwar & France & 1 & Ryals, Lynette J. & United Kingdom & 1 \\
\hline Penz, Bernard & France & 1 & Saghiri, Soroosh & United Kingdom & 1 \\
\hline Laurent Lim, Lâm & France & 1 & Spring, Martin & United Kingdom & 1 \\
\hline Marier, Philippe & France & 1 & Skipworth, Heather & United Kingdom & 1 \\
\hline Alpan, Gülgün & France & 1 & Julien, Denyse & United Kingdom & 1 \\
\hline Ullrich, Kristoph K R & Germany & 1 & Tarafdar, Monideepa & United Kingdom & 1 \\
\hline Transchel, Sandra & Germany & 1 & Qrunfleh, Sufian & USA & 1 \\
\hline Nemati, Yaser & Iran & 1 & Roh, Joseph & USA & 1 \\
\hline Ghadikolaei, AbdolhamidSafaei & Iran & 1 & Tate, Wendy Lea & USA & 1 \\
\hline Madhoshi, Mehrdad & Iran & 1 & Ralston, Peter M. & USA & 1 \\
\hline Turkulainen, Virpi & Ireland & 1 & Rutherford, Brian N. & USA & 1 \\
\hline Danese, Pamela & Italy & 1 & Esper, Terry L. & USA & 1 \\
\hline Chiarini, Andrea & Italy & 1 & Whipple, Judith M. & USA & USA \\
\hline Romano, Pietro & Italy & 1 & Murfield, Monique L.U. & USA \\
\hline Vagnoni, Emidia & Italy & 1 & Grawe, Scott J. & USA & 1 \\
\hline Molinaro, Margherita & Italy & 1 & Gunasekaran, Angappa & USA \\
\hline Bakar, Abu & Malaysia & 1 & Plank, Richard E. & USA & 1 \\
\hline Hamid, Abdul & Malaysia & 1 & Richey, R. Glenn & USA \\
\hline Talib, Ab & Malaysia & 1 & Hooker, Robert & USA \\
\hline Syazwan, Mohamed & Malaysia & 1 & Scott C. Ambrose & USA \\
\hline Bautista Santos, Horacio & México & 1 & Swink, Morgan & USA \\
\hline Fernández Lambert, Gregorio & México & 1 & Stolze, Hannah J. & 1 \\
\hline Bernabé Loranca, María Beatriz & México & 1 & & & 1 \\
\hline Sánchez Galván, Fabiola & México & 1 & & & 1 \\
\hline Martínez Flores, José Luis & México & 1 & & & \\
\hline Sour: Own & & & & \\
\hline
\end{tabular}

Source: Own elaboration, 2018. 